Original Research Article

\title{
Propantheline induced pharmacokinetic variability in lithium bioavailability in human volunteers after co-administration with lithium and imipramine
}

\author{
Preet Sood*, Vikram Bhandari, Narinder Singh, Jaswinder Singh
}

Department of Pharmacology, Sri Guru Ram Das Institute of Medical Sciences and Research, Amritsar, Punjab, India

Received: 14 August 2016 Accepted: 15 September 2016

*Correspondence to:

Dr. Preet Sood,

Email: preetsood@yahoo.co.in

Copyright: (C) the author(s), publisher and licensee Medip Academy. This is an openaccess article distributed under the terms of the Creative Commons Attribution NonCommercial License, which permits unrestricted noncommercial use, distribution, and reproduction in any medium, provided the original work is properly cited.

\begin{abstract}
Background: Lithium is used commonly in bipolar illness. It is co administered with many other drugs like imipramine, fluoxetine to improve the clinical efficacy of the therapy. Co administrations of other drugs like NSAIDS and GIT drugs for various ailments are also common. As this drug possesses a narrow therapeutic range, effect of other drugs on its pharmacokinetic parameters is important to achieve its therapeutic goal as well as to avoid serious adverse effect.

Methods: Total $n=30$ human volunteers were enrolled in the study. After randomization subjects were divided into three study groups. Group 1 was given lithium (900mg) alone while group 2 and 3 were given lithium (900mg) and imipramine $(25 \mathrm{mg})$ at $0 \mathrm{~h}$. Group 3 patients were administered propantheline (15mg) $1 \mathrm{hr}$ prior to lithium and imipramine.

Results: In group 2 ( $\mathrm{Li}+\mathrm{Imp})$ treatment with imipramine produced a significant decrease in $C \max (p<0.01)$, increase in Tmax $(p<0.001)$ and a significant fall in AUC $(p<0.001)$ of lithium. There was no significant change in Kel and hence no change in $\mathrm{T} 1 / 2$ was observed. In group 3 ((Li+Imp+Pro) addition of propantheline accentuated the imipramine induced fall in serum lithium concentration at all the sampling points as shown in Figure 1. It significantly accentuated the imipramine induced fall in Cmax of lithium $(\mathrm{p}<0.05)$ and prolonged the $\mathrm{T}$ max. There was no significant difference between Kel, $\mathrm{T}$ 1/2 and AUC of group 2 ( $\mathrm{Li}+\mathrm{Imp}$ ) versus group 3 ( $\mathrm{Li}+\mathrm{Imp}+$ Pro).

Conclusions: Propantheline even being the anticholinergic drug was unable to show its effect, this is due to high ceiling masking in antagonistic action of imipramine.
\end{abstract}

Keywords: Imipramine, Lithium, Pharmacokinetic parameters

\section{INTRODUCTION}

Lithium is considered as standard mood stabilizer i.e. Normothymotic. It has a low therapeutic index. Optimal serum concentrations appear to be in the range of $0.8-1.5$ $\mathrm{mM}$ for the acute treatment of a manic episode and 0.4$1.2 \mathrm{mM}$ for prophylaxis. ${ }^{3}$ Higher concentrations are more liable to cause side-effects such as tremor, diarrhoea, polyuria and weight gain. ${ }^{4}$ Permanent cerebellar damage is one of the most serious forms of lithium toxicity upon overdose, although this may also appear in the therapeutic range..$^{5}$ Lithium is eliminated almost entirely by renal excretion.
Polypharmacy is often required for the management of bipolar disorder. ${ }^{7}$ Combining lithium with traditional antidepressants particularly TCAs (Imipramine, Amytryptyline, Nortryptyline) for bipolar disorder have proven to be beneficial in many trials. ${ }^{9}$

Imipramine is an effective antidepressant, add on therapy with lithium is coined as first line treatment in bipolar disorder. High doses of Imipramine has led to slow and erratic absorption of drugs like Primidone, Procainamide and Oxyphenbutazone due to anticholinergic action. ${ }^{7}$

Propantheline bromide is a popular antispasmodic drug used for pain. It is claimed to reduce gastric secretion at 
doses which produce only mild side effects. ${ }^{10}$ It is used in day today therapy to counteract abdomen pain due to any reason.

Lithium being an ion does not get metabolized. Absorption and renal excretion are the important factors which can affect lithium levels. The surface area is major determining factor for the absorption. More quickly the drug reaches the intestine, the more exposure to larger and highly perfused surface and hence more is the absorption. $^{2}$

An animal study with lithium and propantheline treated rats has reported a delay in peak plasma concentration as well as time to achieve the peak plasma concentration $(p<0.05)$ of lithium. AUC has significantly changed. ${ }^{4}$

The present study was planned to study whether the change in gut motility by adding propantheline in standard lithium imipramine combination affects the absorption of lithium or not, as lithium possesses narrow therapeutic range.

\section{METHODS}

\section{Clinical protocol}

This was an open, randomized, single dose study conducted at Dayanand Medical College and Hospital, Ludhiana in the Department of Pharmacology. The sample estimation was done in the institutional biochemistry laboratory. 30 adult human volunteers of either sex in good health, as determined by medical history, physical examination and clinical laboratory tests were enrolled. They were divided into 3 groups of 10 each. Institutional review board approval and informed consent from each subject were obtained before the study. The median age and weight of the subjects were 24 (range 20-38) years and 68 (range 57-85) kg. After an overnight fast, Lithium alone (gp1) and lithium+imipramine (group 2, 3) were given to the subjects with $200 \mathrm{ml}$ of water. Propantheline bromide was also given an hour prior to lithium to the study group (group 3). The samples were taken at 1/2, 1, 2, 4, 6 and 24 hr under aseptic condition.

Table 1: Drug administration protocol.

\begin{tabular}{|lll|}
\hline Group & $\mathbf{6 0}$ mins & $\mathbf{0 ~ h r}$ \\
\hline 1 & & Lithium (900mg) \\
\hline 2 & $\begin{array}{l}\text { Lithium+Imipramine } \\
\text { (900mg) }(25 \mathrm{mg})\end{array}$ \\
\hline 3 & $\begin{array}{l}\text { Propantheline } \\
\text { bromide }(15 \mathrm{mg})\end{array}$ & $\begin{array}{l}\text { Lithium+Imipramine } \\
(900 \mathrm{mg})(25 \mathrm{mg})\end{array}$ \\
\hline
\end{tabular}

\section{Drug assays}

Blood samples for lithium concentrations were allowed to clot in vacutainer and serum was separated by centrifugation at $0^{\circ} \mathrm{C}$. Serum samples were stored at or below $-20^{\circ} \mathrm{C}$ until analysis. Serum levels were determined by using ion selective electrode (Synchron El-ise).

A Method of collecting blood sample-under aseptic condition, Jelco cannula was inserted and the first blood sample (Oh) was drawn at the same time and then heparin (1ml) was injected to maintain the patency of cannula.

Serially, the blood samples were collected at $1 / 2 \mathrm{~h}, 1 \mathrm{~h}, 2 \mathrm{~h}$, $4 \mathrm{~h}, 6$ and $24 \mathrm{hr}$ in same manner as the $0 \mathrm{~h}$ sample. Every time before taking sample $1 \mathrm{ml}$ blood was discarded so as to remove heparin and after collecting the sample $1 \mathrm{ml}$ of heparin (1:1000) was injected.

After $6 \mathrm{~h}$ sample cannula was taken out, the volunteers were sent back home and asked to come back again at 9 am for $24 \mathrm{hr}$ sample.

Instrument: Synchrone El-ise system is multi analytic discrete analyser which measures the electrolytes ( $\mathrm{Na}, \mathrm{K}$, $\mathrm{Cl}$, Li). Instrument was standardized with the known value of lithium calibrator to give us the reading in $\mathrm{mEq} / \mathrm{L}$.

The system was set to perform all the calculations internally to produce the final report.

The lithium data was analyzed for various pharmacokinetic parameters $\left(\mathrm{K}, \mathrm{T}_{1 / 2}\right.$, AUC) using one compartment model. Peak plasma concentration (C max), $\mathrm{Kel}, \mathrm{T}^{1 / 2}$ and time to reach maximum max concentration (Tmax) were calculated. The rate constant of max elimination (Kel), half-life of elimination $\left(\mathrm{T}_{1 / 2}\right)$ and area under curve (AUC) were measured by trapezoidal rule.

\section{Pharmacokinetic analysis}

Serum concentration of lithium was subjected to one compartmental pharmacokinetic analysis using WINNONLIN free software. ${ }^{9}$ The maximum serum concentration $\left(\mathrm{C}_{\max }\right)$ and the time of $\mathrm{C}_{\max }\left(\mathrm{T}_{\max }\right)$ were read directly from the concentration-time curve. The area under the concentration-time (AUC) 0, $24 \mathrm{~h}$ was obtained by linear trapezoidal summation.

\section{Statistical analysis}

Mean, standard deviation (SD) and standard error of mean (SEM) of all parameters of the thirty patients divided in three groups of 10 each were calculated. The comparisons were then made with the lithium alone, Lithium and Imipramine and the Lithium and Imipramine and Propantheline. Unpaired t-test was applied and significance was determined from the t-table. Results were taken to be significant if $\mathrm{p}$ was found less than 0.05 at the $18(\mathrm{n} 1+\mathrm{n} 2-2)$ degrees of free. 


\section{RESULTS}

The blood samples were collected at $0 \mathrm{~h}, 1 / 2 \mathrm{~h}, 1 \mathrm{~h}, 2 \mathrm{~h}, 4 \mathrm{~h}$, $6 \mathrm{~h}$ and $24 \mathrm{~h}$. The serum concentration assayed and various pharmacokinetics parameters like Cmax, Tmax, Kel, T12/2, and AUC was calculated for each volunteer.

In lithium alone (group 1) patients, the peak plasma concentration of $75 \mathrm{mEq}$ was attained at $1 \mathrm{~h}$ and followed by a fall which continued throughout the $24 \mathrm{~h}$ observation period.

In group $2(\mathrm{Li}+\mathrm{Imp})$, treatment with imipramine produced a significant decrease in Cmax $(\mathrm{p}<0.01)$, increase in Tmax $(\mathrm{p}<0.001)$ and a significant fall in AUC $(p<0.001)$ of lithium. There was no significant change in Kel and hence no change in $\mathrm{T}_{1 / 2}$ was observed. Direct calculation of Kabs was not performed as there was only one data point between 0 time and $\mathrm{C}$ max.

Table 2: Lithium concentration ( $\mathrm{mEq} / \mathrm{l})$ after a single Dose of Lithium versus Lithium+Imipramine Versus Lithium+Imipramine+Propantheline $(n=30)$.

\begin{tabular}{|llll|}
\hline $\begin{array}{l}\text { Time } \\
\text { (h) }\end{array}$ & $\begin{array}{l}\text { Group-1 } \\
\text { (Lithium) }\end{array}$ & $\begin{array}{l}\text { Group-2 } \\
\text { (Lithium+ } \\
\text { Imipramine) }\end{array}$ & $\begin{array}{l}\text { Group -3 } \\
\text { (Lithium+ } \\
\text { Imipramine+ } \\
\text { Propantheline) }\end{array}$ \\
\hline 0 & 0 & 0 & 0 \\
\hline 0.5 & $0.29 \pm 0.018$ & $0.22 \pm 0.025 *$ & $0.19 \pm 0.009 * * *$ \\
\hline 1 & $0.75 \pm 0.013$ & $0.52 \pm 0.031 * * *$ & $0.44 \pm 0.022 * * *$ \\
\hline 2 & $0.68 \pm 0.017$ & $0.60 \pm 0.061 * *$ & $0.51 \pm 0.028 * * *$ \\
\hline 4 & $0.61 \pm 0.08$ & $0.48 \pm 0.021 * * *$ & $0.45 \pm 0.028 * * *$ \\
\hline 6 & $0.48 \pm 0.023$ & $0.36 \pm 0.025 * * *$ & $0.32 \pm 0.030 * * *$ \\
\hline 24 & $0.26 \pm 0.022$ & $0.17 \pm 0.011 * * *$ & $0.15 \pm 0.012 * * *$ \\
\hline
\end{tabular}

Table 3: Pharmacokinetic parameters of lithium versus lithium+Imipramine Vs

lithium+Imipramine+Propantheline $(\mathbf{n = 3 0})$.

\begin{tabular}{|llll|}
\hline $\begin{array}{l}\text { Pharmacoki } \\
\text { netic } \\
\text { parameters }\end{array}$ & $\begin{array}{l}\text { Group-1 } \\
\text { (Lithium) }\end{array}$ & $\begin{array}{l}\text { Group-2 } \\
\text { (Lithiu+Imi } \\
\text { pramine) }\end{array}$ & $\begin{array}{l}\text { Group -3 } \\
\text { (Lithium+ } \\
\text { Imipramin+Pro } \\
\text { pantheline) }\end{array}$ \\
\hline $\begin{array}{l}\text { Cmax } \\
\text { (mEq/L) }\end{array}$ & $0.75 \pm 0.01$ & $0.62 \pm 0.016 * *$ & $0.54 \pm 0.2231 * * * \#$ \\
\hline Tmax (hrs) & $1 \pm 0.0$ & $2.1 \pm 0.23 * * *$ & $2.8 \pm 0.327 * * *$ \\
\hline Kel (hrs-1) & $0.039 \pm 0.0026$ & $0.049 \pm 0.0041$ & $0.050 \pm 0.0041$ \\
\hline $\mathrm{T}_{1 / 2}(\mathrm{hrs})$ & $18.19 \pm 1.2053$ & $14.97 \pm 1.0422$ & $14.71 \pm 1.2810 *$ \\
\hline $\begin{array}{l}\mathrm{AUC} \\
(\mathrm{mEq} . \mathrm{h} / \mathrm{L})\end{array}$ & $17.01 \pm 0.7586$ & $\begin{array}{l}11.01 \pm 0.5933 \\
* * *\end{array}$ & $10.06 \pm 0.6972 * * *$ \\
\hline
\end{tabular}

$* \mathrm{P}<0.05, * * \mathrm{P}<0.01, * * * \mathrm{P}<0.001$ As compared to group -1

$\# \mathrm{P}<0.05, \# \# \mathrm{P}<0.01, \# \# \mathrm{P}<0.001$ As compared to group-2

In group 3 ( $\mathrm{Li}+\mathrm{Imp}+\mathrm{Pro})$, addition of propantheline accentuated the imipramine induced fall in serum lithium concentration at all the sampling points as shown in Table 2. It significantly accentuated the imipramine induced fall in Cmax of lithium $(\mathrm{p}<0.05)$ and prolonged the Tmax. There was no significant difference between
Kel, T1/2 and AUC of group 2 (Li+Imp) versus group 3 (Li+Imp+Pro).

\section{DISCUSSION}

Lithium Carbonate is the of the most extensively used medicine or pharmacotherapeutic agent used by psychiatrists as well as physicians due to its high efficacy in management of mania and depression. Concomitant administration of two or more drugs always has the possibility of pharmacokinetic and pharmacodynamic interactions which can benefit or limit the final therapeutic effect and can also combat some ADRs.

Studies proving the effect of various drugs on absorption of lithium are very few. Propantheline has been shown to increase the time to achieve maximum concentration (Tmax) while reducing the peak plasma concentration (Cmax) indicating a reduction in the rate of absorption of lithium. Change in AUC was small, indicating little effect on the extent of absorption. ${ }^{12}$

In our study, in lithium only group $\mathrm{C}$ max was achieved in $1 \mathrm{hr}$ indicating rapid absorption of lithium. This corresponds with many published reports which stated that with conventional dose, lithium absorption is rapid while peak is attained in $0.5-3 \mathrm{~h}$ after single dose. ${ }^{8}$

A peak was followed by a faster fall till $6 \mathrm{~h}$, followed by a slower fall in $24 \mathrm{~h}$ this indicates an initial distribution Phase (a) followed by a slower elimination phase (b) with advantage of hind sight, it can be said that another sampling point should have been kept in between $6 \mathrm{~h}$ and $24 \mathrm{~h}$.

Imipramine significantly lowered the peak plasma concentration $(\mathrm{p}<0.001)$ and delayed the attainment of peak plasma concentration i.e. increase in $\mathrm{T} \max$ of lithium when administered along with it $(\mathrm{P}<0.05)$.

This is probably because of anticholinergic effect of imipramine as it results in slowing of gastric emptying and increases transit time. As lithium stays more time in stomach but absorbed in intestine resulting in decreased rate and extent of absorption manifested by decreased Cmax, increases Tmax and AUC. ${ }^{11}$ However there was no effect on Keland AUC.

Interaction of lithium and imipramine is less studied but the combination is very popular and widely used and have synergistic effects in resistant and bipolar depression. $^{14,15}$

In group 3 adding propantheline in lithium + imipramine combination has decreased the peak plasma concentration $(\mathrm{p}<0.01)$. All parameters point to a further reduction in lithium absorption over and above the reduction produced by imipramine even though the most changes were not statistically significant. Thus propantheline appears to have added to the significant anti muscarinic effects of 
Imipramine resulting in decrease in lithium absorption. It is due to ceiling on the effects of competitive antagonists, a marked synergistic action could not have taken place.

\section{CONCLUSION}

Propantheline when prescribed with lithium and imipramine significantly decreased the lithium concentration as compared to imipramine. This may result in therapeutic failure. Moreover, it is likely to aggravate the anticholinergic adverse drug reactions of imipramine like retention of urine, dry mouth, decreased secretions, blurring of vision. So the co- administration of Propantheline and imipramine is to be avoided.

\section{ACKNOWLEDGEMENT}

I hereby acknowledge the support of the Biochemistry laboratory team of Dayanand Medical College, for helping me in the completion of my project.

Funding: No funding sources Conflict of interest: None declared

Ethical approval: The study was approved by the Institutional Ethics Committee of Dayanand Medical College Ludhiana

\section{REFERENCES}

1. Bellibaş SE, Tuğlular I, Kayali A. The effect of delayed gastric emptying and absorption on pharmacokinetic parameters of lithium. Eur J Drug Metab Pharmacokinet. 1995 Apr-Jun;20(2):129-33.

2. Nolen WA, Weisler RH. The association of the effect of lithium in the maintenance treatment of bipolar disorder with lithium plasma levels: a post hoc analysis of a double-blind study comparing switching to lithium or placebo in patients who responded to quetiapine Bipolar Disord. 2013 Feb;15(1):100-9.

3. Lauritsen BJ, Mellerup ET, Plenge P, Rasmussen S, Vestergaard P, Schou. Serum lithium concentrations around the clock with different treatment regimens and the diurnal variation of the renal lithium clearance. Acta Psychiatr Scand. 1981;64(4):314.

4. Türck D, Heinzel G, Luik G. Steady-state pharmacokinetics of lithium in healthy volunteers receiving concomitant meloxicam $\mathrm{Br} \mathrm{J}$ Clin Pharmacol. 2000 Sep;50(3):197-204.

5. Hunter R. Steady State pharmacokinetics of Lithium Carbonate in healthy subjects $\mathrm{Br}$. J. pharmac. 1988;25:375-80.

6. Muller MJ. Therapeutic drug monitoring of tricyclic antidepressants: how does it work under clinical conditions? Pharmaco Psychiatry. 2003;36:98-104.

7. Perry PJ, Alexender B, Prince RA, Dumen F. The utility of a single point dosing Protocol for predicting steady State Lithium Levels. Br J Psychiatry. 1986;148:401-5.

8. Chao C, Veronese L, Yin Y. The effects of lamotrigine on the pharmacokinetics of lithium $\mathrm{Br} \mathrm{J}$ Clin Pharmacol. 2000;50(3):193-5.

9. Finley PR, Warner MD, Peabody CA. Clinical Relevance of Drug Interactions with Lithium. Clin Pharmacokin. 1995;29:172-91.

10. Gelenberg A, Kane J, Keller M. Comparison of standard and low serum levels of lithium for maintenance treatment of bipolar disorder. N Engl J Med. 1989;321:1489-93.

11. Cookson J. Lithium: Balancing risks and benefits. $\mathrm{Br}$ J Psychiatry. 1997;171:120-4.

12. Frye MA, Kimbrell TA, Dunn RT. Gabapentin does not alter single-dose lithium pharmacokinetics; J Clin Psycho Pharmacol. 1998;18:461-4.

13. Apseloff G, Wilner KD, Von Deutsch DA, Gerber N. Tenidap sodium decreases renal clearance and increases steady-state concentrations of lithium in healthy volunteers. $\mathrm{Br} \mathrm{J}$ Clin Pharmacol. 1995;39:25-8.

Cite this article as: Sood P, Bhandari V, Singh N, Singh J. Propantheline induced pharmacokinetic variability in lithium bioavailability in human volunteers after co-administration with lithium and imipramine. Int J Basic Clin Pharmacol 2016;5:251720. 